African Crop Science Journal by African Crop Science Society is licensed under a Creative Commons Attribution 3.0 Uganda License. Based on a work at www.ajol.info/ and www.bioline.org.br/cs DOI: http://dx.doi.org/10.4314/acsj.v25i1.8

\title{
PREVALENCE OF ANGULAR LEAF SPOT DISEASE AND SOURCES OF RESISTANCE IN COMMON BEAN IN EASTERN DEMOCRATIC REPUBLIC OF CONGO
}

\author{
R. KIJANA, M. ABANG ${ }^{1}$, R. EDEMA ${ }^{2}$, C. MUKANKUSI ${ }^{1}$ and R. BURUCHARA ${ }^{3}$ \\ National Institute for Study and Agronomic Research (INERA), Mulungu, D/S Bukavu, South Kivu, \\ Democratic Republic of Congo \\ ${ }^{1}$ International Centre for Tropical Agriculture (CIAT), P. O. Box 6247, Kampala, Uganda \\ ${ }^{2}$ College of Agricultural and Environmental Sciences, Makerere University, P. O. Box 7062, Kampala, Uganda \\ ${ }^{3}$ International Centre for Tropical Agriculture (CIAT), P. O. Box 823, Nairobi, Kenya \\ Corresponding author: c.mukankusi@ cgiar.org
}

(Received 1 July, 2016; accepted 17 February, 2017)

\begin{abstract}
Angular leaf spot (Pseudocercospora griseola Crous U, Brown) is one of the most important diseases hindering common bean (Phaseolus vulgaris L.) production in the Great Lakes Region of Africa, including the Democratic Republic of Congo. The disease causes extreme yield losses, estimated at 384.2 tonnes per year, in Sub-Saharan Africa. Little is known about the distribution, severity and incidence of the disease and the effect of agronomic practices and environmental factors on the disease prevalence in the country to facilitate interventions. A field survey was conducted during two crop seasons, February to June and September to January, in two main beans growing zones of eastern DRC namely; sub-humid highland and sub-humid mid altitude at low latitudes, in South and North Kivu, respectively. Severity and incidence of angular leaf-spot and other occurring diseases were assessed on common bean plants in farmers' fields. Angular leaf spot in these fields had an average severity index (PSI) of $49.9 \%$. PSI was significantly different $(\mathrm{P}<0.05)$ between districts and seasons. Using multiple regression analysis, independent variables: growth stage, cropping system, districts and altitude were shown to have significant influence on the observed PSI $(\mathrm{P}<0.05)$ with $\mathrm{R}^{2}=96.2 \%$. The highest severity (PSI=59.7\%) was observed in Kabare district, and the lowest in Uvira district (PSI=39.5\%). Screening of a set of 37 released common bean varieties in DRC using virulent Andean and Mesoamerican isolates identified four resistant bean varieties; ARA 4, COD MLV 059, MLV 224/94B, LSA 144 and Mexico 54. Some of these varieties possess useful traits, in addition to acceptable seed market class, and are hence recommended as suitable parents for ALS resistant variety development and promotion in ALS prone environments.
\end{abstract}

Key Words: Phaseolus vulgaris, Pseudocercospora griseola, severity

\section{RÉSUMÉ}

La tache angulaire (Pseudocercospora griseola Crous U, Brown) est l'une des maladies les plus importantes qui entravent la production de haricot commun (Phaseolus vulgaris L.) dans la région des Grands Lacs d'Afrique, y compris la République Démocratique du Congo. La maladie provoque des pertes de rendement extrêmes, estimées à 384.2 tonnes par an en Afrique Sub-Saharienne. Ily a encore peu de connaissance sur la distribution, la gravité et l'incidence de la maladie et l'effet des pratiques agronomiques et des facteurs environnement aux sur la prévalence de la maladie dans le pays pour faciliter les interventions. Une enquêtesur le terrain a étémenée pendant deux saisons de récolte, de Février à Juin et de Septembre à janvier, dans deux zones principals de culture 
de haricots de l'est de la RDC, à savoir: Sous-humides de haute altitude et sous-humides à basse altitude, au Sud et au Nord-Kivu. La gravité et l'incidence de la tache angulaire des feuilles et d'autres maladies ont été évaluées sur les plants de haricots dans les champs des agriculteurs. Ces champs étaient infestés par la maladie, avec unindice de gravité moyen (IPS) de 49.9\%. PSI était significativement différent $(\mathrm{P}<0.05)$ entre districts et saisons. En utilisant l'analyse de régression multiple, les variables indépendantes: stade de croissance, système de culture, districts et altitude ont montré une influence significative sur le PSI observé $(\mathrm{P}<0.05)$ avec R2 $=96.2 \%$. La sévérité plus élevée (PSI $=59.7 \%$ ) a été observée dans le district de Kabare et la plus faible dans le district d'Uvira $(\mathrm{PSI}=39,5 \%)$. La sélection d'un lot de 37 variétés de haricot distribuées en RDC utilisant des isolats virulents Andins et Mésoaméricains a permis d'identifier quatre variétés de haricots résistants; ARA 4, COD MLV 059, MLV 224 / 94B, LSA 144 et Mexique 54. Certaines de ces variétés présentent des traits utiles en plus de son acceptabilité sur lemarché des semences, et sont donc recommandés comme des parents appropriés pour le développement et la promotion des variétés résistantes ALS.

Mots Clés: Phaseolus vulgaris, Pseudocercospora griseola, séverité

\section{INTRODUCTION}

Common bean (Phaseolus vulgaris L.) is grown in diverse environmental conditions in the sub-Saharan Africa. The Democratic Republic of Congo is among the main producers and consumers of the crop in the region (Wortmann et al., 1998; Katungi et al., 2009), with bean production estimated at 248,957 metric tonnes annually (FAO, 2010). The Eastern part of the country provides more than half of the country's bean production (USAID 2010; FAO, 2014).

However, common bean yields remain low at farmer level, averaging $0.3 \mathrm{t} \mathrm{ha}^{-1}$ (CIALCA, 2009) to $0.542 \mathrm{t} \mathrm{ha}^{-1}$ (FAO STATS, 2012), though potential yield in the country ranges between 1000-2500 $\mathrm{kg} \mathrm{ha}^{-1}$ for bush beans and $1500-4000 \mathrm{~kg} \mathrm{ha}^{-1}$ for climbing beans (Mbikayi, 2002).

Production is hampered by many diseases including angular leaf spot (ALS) caused by Pseudocercospora griseola Crous U, Brown (Crous et al., 2006). Angular leaf spot is a major limiting factor for bean production, in eastern and central Africa, where losses of 374,800 tonnes annually have been reported (Wortmann et al., 1998). Pyndji (1992) reported yield losses of up to $80 \%$ attributed to ALS in DRC.

Various production practices and variation in climatic conditions are thought to influence disease occurrence, epidemics development and damage to the crops, under field conditions (Stenglein et al., 2003; Allerent and Savary, 2005; Mwangombe et al., 2007).

Several management practices such as growing varietal mixture and intercropping have been used to control the disease (Wortmann et al., 1998; Busogoro et al., 1999; Mahuku et al., 2002), and the effect of management practices, especially, intercropping/cropping system on the diseases incidence or prevalence has been documented (Boudreau, 1993; Fininsa and Yuen, 2002; Fernandez et al., 2011). However, losses associated with high ALS disease epidemics still prevail (Yesuf and Sangchote, 2005) and have been shown to vary in different cropping systems (Schoeny et al., 2010).

Resistant varieties have been suggested as a cost effective strategy to manage the disease at small scale farmer level (Pastor Corrales $e t$ al., 1998; Busogoro et al., 1999; Mahuku et al., 2009). However, deployment of resistant varieties for the control of ALS requires understanding of others production factors, especially environmental, cultural and epidemiological, upon which the disease management can be anchored (Singh, 2007).

This study aimed at investigating the extent of ALS distribution, incidence, severity and the relationship of the disease parameters with management practices and agro ecological factors in eastern Democratic Republic of Congo (DRC). 


\section{MATERIALS AND METHODS}

The study area. The study was conducted in two main beans agro-ecological zones in eastern Democratic Republic of Congo (DRC), in the Kivu Province. The two zones included i) the African Bean Production Environment II (AFBE2) 2, in the sub-humid highland areas of Walungu, Kabare and Uvira districts, and ii) AFBE7 in sub-humid mid-altitude at low latitudes in three districts, Rutshuru, Masisi and Lubero (Wortman et al., 1998). They were selected based on their suitability and high potential for bean production; the sub-humid highlands (HL) at more than 1500 metre above sea level (masl) in AFBE 2 and the sub-humid mid-altitudes (MA) ranging between 1000-1500 m.a.s.l in AFBE 7 (Wortmann et al.,1998).

In general, the Kivu highlands and North Kivu landscape are characterised by volcanic soils (Musila 2009; USAID, 2010; Walangululu et al., 2011); while South Kivu is characterised by red clay like soils (Ross et al., 2009). The rainfall in the Kivu region is bimodal; the main season extends from mid-September up to midJanuary; and the short rain seasonstarting midFebruary up to mid-June. The mean rainfall ranges between $1500-1800 \mathrm{~mm}$ per annum (Walangululu et al., 2011) and mean temperature in the Kivu province (eastern part) is $18^{\circ} \mathrm{C}$ (Musila, 2009).

Prevalence of angular leaf spot. A field survey was conducted in June 2011 (short rainy season) and November 2012 (long rainy season) in South and North Kivu in eastern DRC. In each of the six districts, fourteen farmers' fields separated by about $5 \mathrm{Km}$, were randomly selected along the road or path within the village. These fields were assessed for ALS bean disease occurrence and severity; while walking, following " $\mathrm{W}$ " path within the field (Delp et al.,1986; Crabb et al., 1994).

Boundaries of one squared meter were delimited in each corner of the "W" and where the lines intersected in the middle. Five sampling points were selected, one in the middle of the field and one at each of the corner in each field, following the "W" pattern. The incidence and severity of the major bean diseases was recorded in the delimited area, in addition to plant density, cropping system, grain type and weed status.

A total of 168 fields were assessed ( 2 agroecologies $\mathrm{x} 3$ districts $\mathrm{x} 14$ fields $\mathrm{x} 2$ seasons). GIS data were recorded for each field.

Disease incidence was evaluated based on percentageof infected plants in a field (Schoonhoven and Pastor-Corrales,1987), while severity was assessed using a 1 to 9 CIAT scale (Schoonhoven and PastorCorrales,1998). Severity data were summarised, transformed into percentage severity index (PSI), which was calculated using the formula below (Sahile et al., 2008).

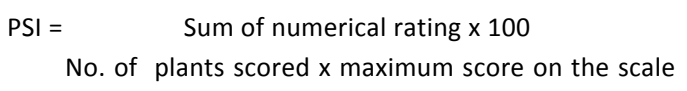

ALS incidence and severity (PSI) were classified into distinct variable classes of binominal qualitative data, with class boundaries of $<50 \%$ and $>50 \%$ for PSI, and $<75 \%$ and $>75 \%$ for incidence. A contingency table of incidence and severity of the independent variables was generated to represent the distribution of fields according to data classification. Data were then subjected to analysis of variance, using GenStat software Version 13.0 and multiple linear regression analysis was performed using Microsoft Excel. Furthermore, diseased leaf samples showing ALS symptoms were collected on small and medium seeded (Mesoamerican) and on large seeded (Andean) plants for laboratory test and varieties screening.

Sources of resistance to ALS. Thirty seven common bean breeding lines (Table 1) sourced from the National Institute of Study and Agronomic Research (INERA), Mulungu in eastern DRC, were evaluated in a screen house at the International Centre for Tropical Agriculture (CIAT) station situated at the 
TABLE 1. List and characteristics of common bean varieties sourced from INERA and screened for angular leaf spot resistance in eastern Democratic Republic of Congo

\begin{tabular}{|c|c|c|c|}
\hline Varieties & Grain colour & 100 seed weight (gms) & Size \\
\hline MEXICO 54 & Pink & - & Large \\
\hline ARA 4 & Red mottled & 42 & Large \\
\hline CODMLV 059 & Red mottled & 45 & Large \\
\hline LSA 144 & Red & 19 & Small \\
\hline MLV 224/94B & Red & 33 & Medium \\
\hline BRB 194 & Red & 35 & Medium \\
\hline CAL 143 & Red mottled & - & Large \\
\hline CNF 5520 & Red mottled & 49 & Large \\
\hline CODMLB 001 & Purple mottled & 29 & Medium \\
\hline MORE 88002 & Yellow & 28 & Medium \\
\hline AND 620 & Red mottled & 33 & Medium \\
\hline CODMLB 078 & Cream & 32 & Medium \\
\hline AFR 708 & Red mottled & 34 & Medium \\
\hline CODMLB 033 & Red mottled & 39 & Medium \\
\hline CODMLB005 & Red mottled & 35 & Medium \\
\hline G5686 & Brown mottled & 36 & Large \\
\hline НМ-21-7 & Red mottled & 36 & Large \\
\hline NUA 99 & Red mottled & 35 & Medium \\
\hline NUA 100 & Red mottled & 36 & Large \\
\hline NUA 86 & Red mottled & 36 & Large \\
\hline NUA 92 & Red mottled & 38 & Large \\
\hline RWR 10 & Red kidney & 33 & Medium \\
\hline CODMLV 056 & Purple mottled & 38 & Large \\
\hline NUA 8 & Red mottled & 38 & Large \\
\hline M'SOLE & Brown & 18 & Small \\
\hline NGUAKU-NGUAKU & Yellow & 36 & Large \\
\hline NUA 91 & Red mottled & 37 & Large \\
\hline ACC 714 & Black & 14 & Small \\
\hline CAL 96 & Red mottled & - & Large \\
\hline CODMLV 052 & Purple mottled & - & \\
\hline K 131 & Carioca & 13 & Small \\
\hline KIANGARA & Yellow & 29 & Medium \\
\hline MLB 49-89A & Black & 22 & Small \\
\hline NAMULENGA & Black tuttle & 34 & Medium \\
\hline NUA 64 & Red mottled & 38 & Large \\
\hline NUA 93 & Red mottled & 35 & Medium \\
\hline RWR 2245 & Red mottled & 36 & Large \\
\hline RWR 362 & Red & 21 & Small \\
\hline VNB81010 & Black & 29 & Medium \\
\hline ZKA 93-10M/95 & Yellow & 26 & Medium \\
\hline ZKA 98-6M/95 & Purple & 15 & Small \\
\hline
\end{tabular}

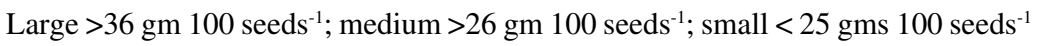


National Agricultural Research Laboratories Institute, (NARL) - Kawanda, in Uganda.

The experiment was laid out as a randomised complete block design (RCBD) with three replications. In each replication, five seeds of each of the 37 breeding lines and three resistant checks; Mexico 54, G5686 and CAL 143 and one susceptible check; CAL 96 were planted in 5 litre plastic pots containing presterilised soil.

Seventeen days after planting, two virulent isolates; SK 146, pathotype 57-39 and SK 126, pathotype 61-39 were used to challenge the 37 INERA common bean accessions and the four checks (Table 1). The isolates had been collected and isolated from diseased plants in South Kivu during the field survey, and given a unique identifier code (SK = South Kivu) and isolate number (SK 126). The pathotype numbers, 57-39 and 61-39 separated by dashes represent the degree of virulence based on binary analysis. In the case of SK 126 pathotype 61-39, the first number, 61 was obtained by adding the binary values of the susceptible Andean (large seeded) differential cultivars, each of which was given a letter: acdef: $1+4+8+16+32=61$. The second number, 39 , was obtained by adding the binary values of the susceptible Middle American cultivar (Pastor-Corrales et al., 1998).

Inoculation and evaluation were conducted according to a protocol described by PastorCorrales et al. (1998). Disease evaluation on individual plants was done at 10,13, 17, 19 and 21 days after inoculation, using a 1-9 CIAT standard rating scale (Schoonhoven and Pastor-Corrales, 1987), where 1= immunity (no visible symptoms) and $9=$ very infected.

Data were subjected to ANOVA using GentStat Version 13.0 and the varieties were then classified according to their reactions to the disease with those scoring less than 3 being classified as resistant, 4-6 intermediate and 79 susceptible (Schoonhoven and PastorCorrales, 1987).

\section{RESULTS}

Disease incidence and severity. Angular leaf spot (ALS) was the most prevalent bean disease in over $95 \%$ of the fields. ALS incidence varied from 75 to $100 \%$ among the sampled fields, with over $98 \%$ of the farms having ALS incidence of more than $75 \%$ (Fig. 1). Rust, common bacterial blight (CBB), anthracnose (Anth), ascochyta (Asco) and Halo blight (HB)

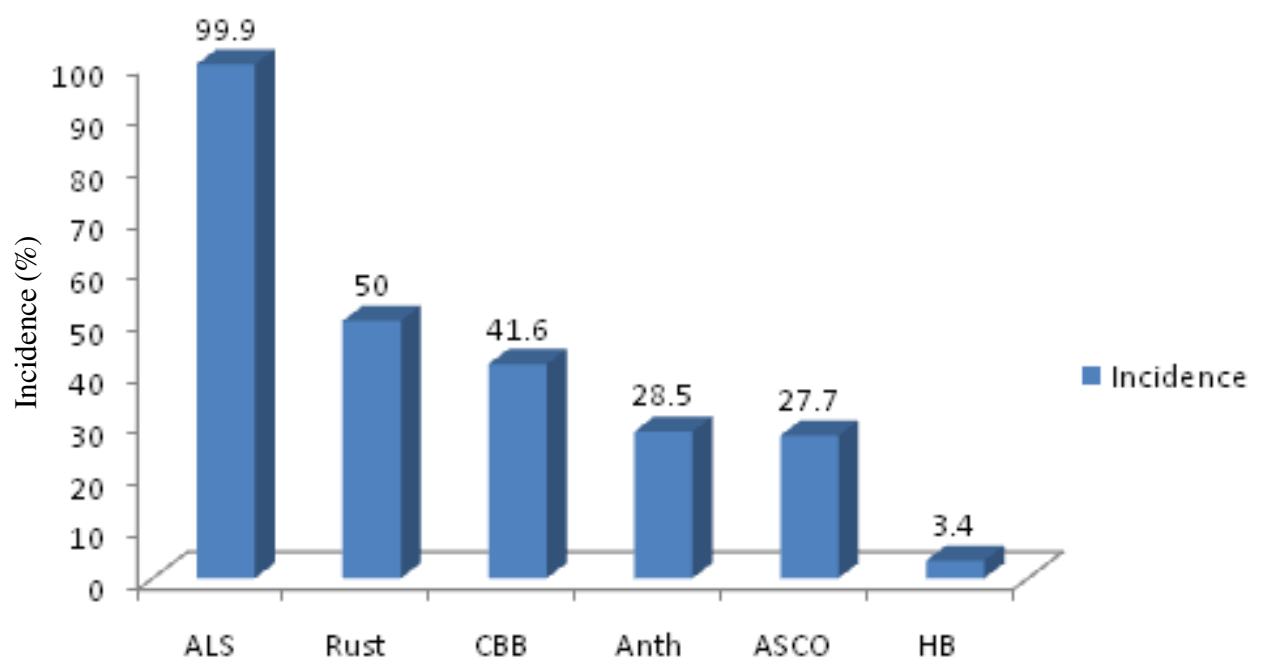

Figure 1. Incidence of six foliar bean diseases in two agro ecological zones of eastern Democratic Republic of Congo (2011 B). 
were also observed with the high incidences in the order of 50, 41,28.5, 27.7 and $3.4 \%$, respectively (Fig. 1).

Angular leaf spot severity index (PSI) was generally high (mean $=49.7 \%$ ) and varied significantly among districts $(\mathrm{P}=0.04)$ and, across growing seasons $(\mathrm{P}=0.009)$. There was a significant interaction between season and districts (Table 2). The maximum severity index (PSI) value of ALS disease was 79.8\%; while the minimum was $24.5 \%$. Mean severity index (PSI) was high in Kabare district located in moderately high altitude (PSI $=59.7 \%$ ), while Uvira district located in low altitude had the lowest mean (PSI $=39.5 \%$ ). Across the two seasons, PSI was conversely low at very high altitudes. Similarly, across the two seasons, PSI was highest at high altitudes (Table 2 and Fig. 2).

A multiple regression model indicated that independent variables: season, district, altitude, growth stage and crop system significantly

TABLE 2. Percentage severity index (PSI) of Angular leaf spot in six districts of eastern Democratic Republic of Congo

\begin{tabular}{llcccc}
\hline No. & Districts & Agroecology & Mean PSI 2011 B & Mean PSI 2012 A & $\begin{array}{c}\text { Combined mean PSI } \\
2011 / 2012^{1}\end{array}$ \\
\hline 1 & Uvira & lowland & 36.0 & 43.1 & $39.5 \mathrm{a}$ \\
2 & Rusthuru & lowland & 42.1 & 52.4 & $47.2 \mathrm{~b}$ \\
3 & Lubero & highland & 46.1 & 51.4 & $48.7 \mathrm{bc}$ \\
4 & Walungu & highland & 48.0 & 52.6 & $50.3 \mathrm{bc}$ \\
5 & Masisi & highland & 56.7 & 49.6 & $53.2 \mathrm{c}$ \\
6 & Kabare & highland & 57.8 & 61.6 & $59.7 \mathrm{~d}$ \\
\hline
\end{tabular}

${ }^{1}$ Number followed by the same letter in the same column are not significantly different $(\mathrm{P}<0.05)$

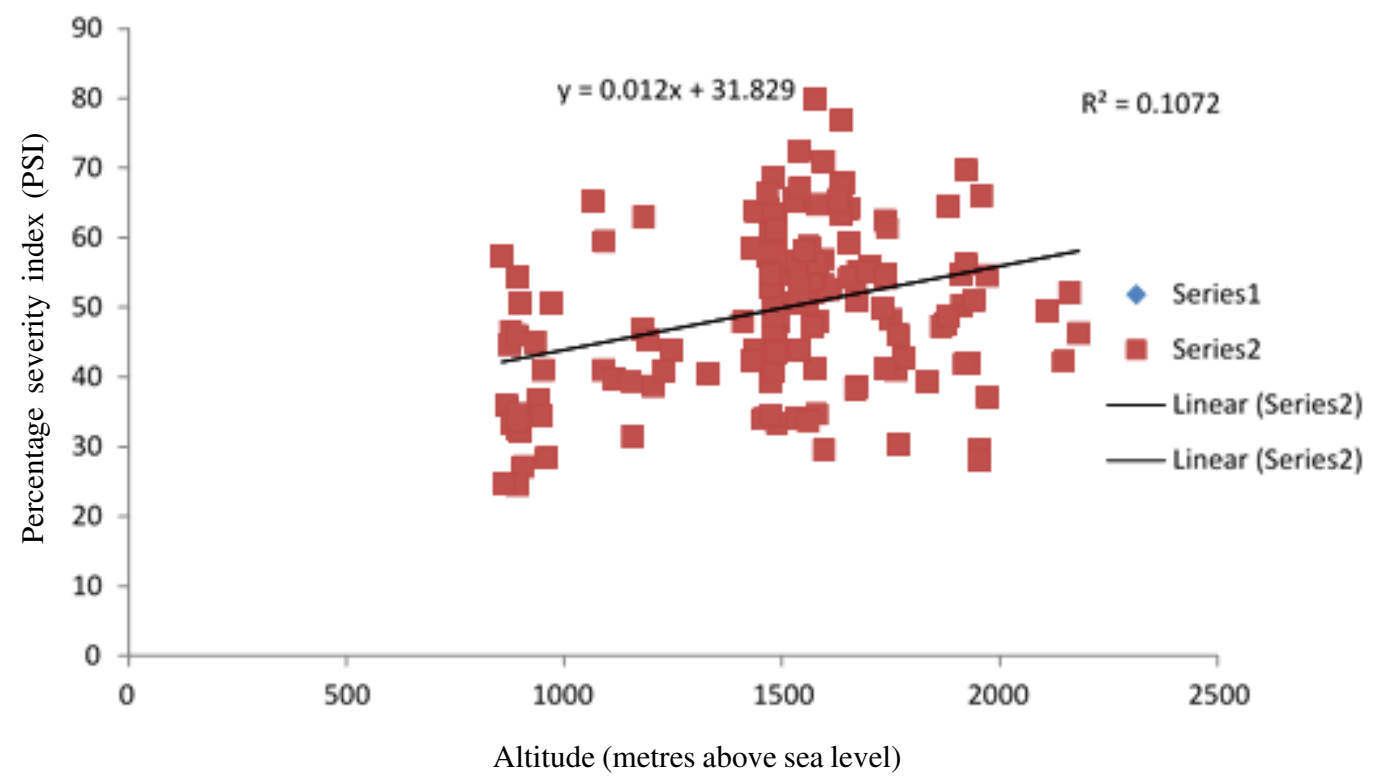

Figure 2. Effect of altitude on percentage severity index (PSI) of angular leaf spot in two agro ecological zones of eastern Democratic Republic of Congo. 
contributed to ALS PSI,with $\mathrm{R}^{2}=96.2 \%$. The variables: growth stage, altitude, and districts were highly significant (Tables 2 and 3). A positive but, weak relationship was observed between precipitation and PSI $\left(\mathrm{r}^{2}=10.7 \%=\right)$, with areas receiving more than $1200 \mathrm{~mm}$ annual rainfall having higher PSI than those receiving less rainfall (Fig. 2). Angular leaf spot disease severity was slightly reduced in mono-cropping compared to intercropping systems (Tables 3 and 4)

Sources of resistance to ALS. Significant differences $(\mathrm{P}<0.001)$ were observed among the test varieties for reaction to ALS disease (Tables 5 and 6). Among the 37 accessions tested, four (representing 10.81\%) showed resistance, 13 (35.14\%) intermediate and 23 $(62.16 \%)$ susceptible reactions to the $P$. griseola isolate SK 126, (pathotype 61-39) (Table 7). In the case of isolate SK 146 (pathotype 57-39), eight varieties (21.62\%) were resistant, 19 varieties $(51.35 \%)$ intermediate and 13 varieties $(35.14 \%)$ susceptible (Table 8 ). Two bush bean lines, LSA 144 and ARA 4 and two climbing beans, MLV 224/94B and CODMLV 059 varieties showed resistance to the both $P$. griseola isolates (Tables 7 and 8). The ALS resistant check, Mexico 54 maintained resistance to the two isolates; while other varieties reported to be resistant in the region and elsewhere, e.g. variety CAL 143 (Aggarawal et al., 2004) and G 5686 (Mahuku et al., 2009) showed intermediate resistance with disease scores of 4 and 5 on a 1-9 scale. The susceptible check, CAL 96 proved highly susceptible to all isolates with a score 9 (Tables 7 and 8).

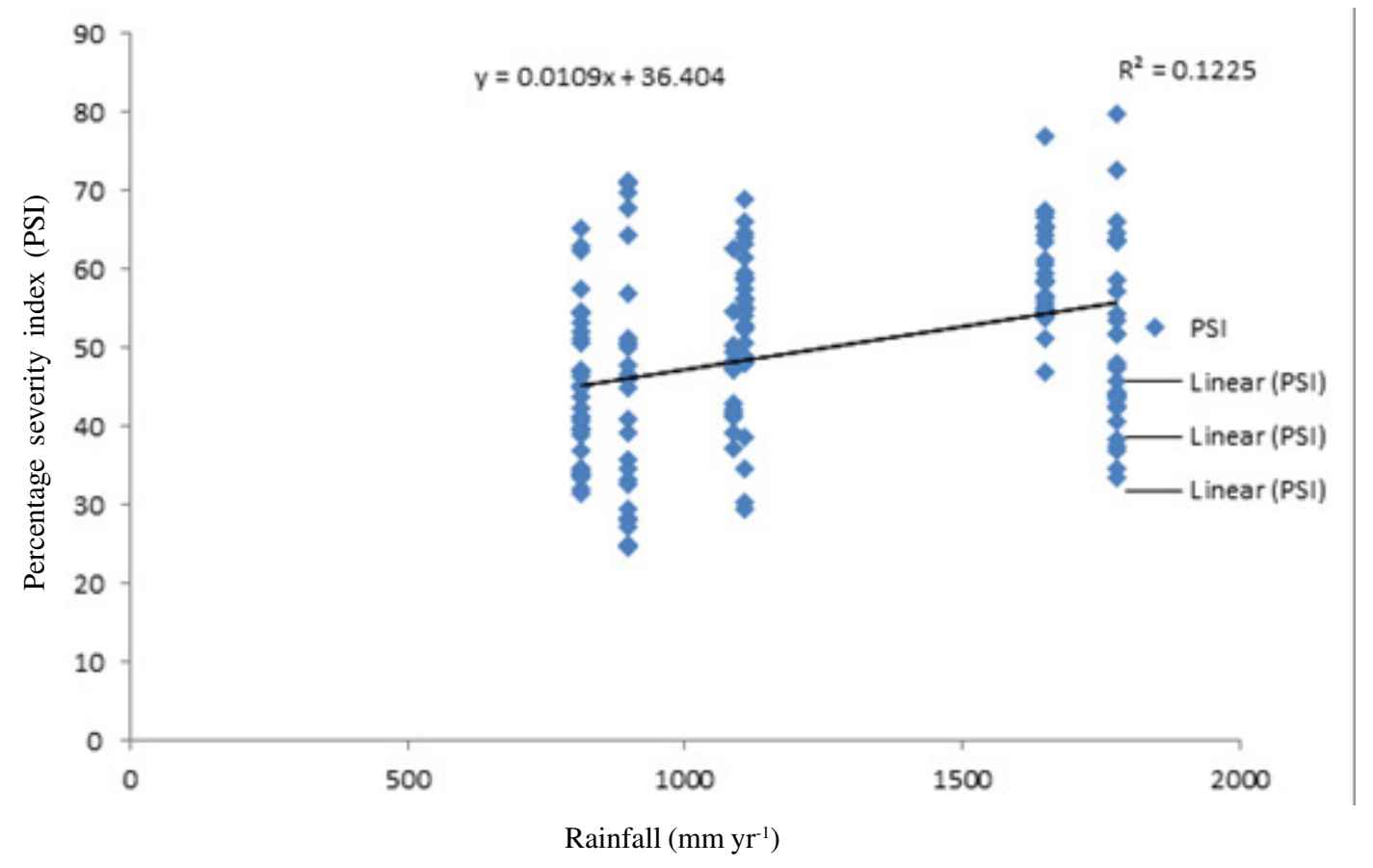

Figure 3. Effect of precipitation on percentage severity index (PSI) of angular leaf spot in two agro ecological zones of eastern Democratic Republic of Congo. 
TABLE 3. Independent variable by disease contingency table of ALS for crop season 2011 and 2012 in eastern Democratic Republic of Congo

\begin{tabular}{|c|c|c|c|c|c|}
\hline \multirow[t]{3}{*}{ Variables } & \multirow[t]{3}{*}{ Variable class } & \multicolumn{4}{|c|}{ *Number of fields with ALS } \\
\hline & & \multicolumn{2}{|c|}{ Incidence } & \multicolumn{2}{|c|}{ Severity } \\
\hline & & $<75 \%$ & $>75 \%$ & $<50 \%$ & $>50 \%$ \\
\hline \multirow[t]{6}{*}{ Districts } & Masisi & 0 & 28 & 7 & 21 \\
\hline & Rusthuru & 0 & 28 & 14 & 14 \\
\hline & Lubero & 0 & 20 & 6 & 14 \\
\hline & Uvira & 0 & 28 & 18 & 10 \\
\hline & Walungu & 2 & 26 & 10 & 18 \\
\hline & Kabare & 0 & 28 & 2 & 26 \\
\hline \multirow[t]{2}{*}{ Altitude } & $<1200$ masl & 0 & 32 & 29 & 4 \\
\hline & $>1200$ masl & 2 & 126 & 56 & 71 \\
\hline \multirow[t]{2}{*}{ Plant density } & $<20$ plants $/ \mathrm{m}^{2}$ & 0 & 83 & 45 & 38 \\
\hline & $>20$ plants $/ \mathrm{m}^{2}$ & 2 & 75 & 39 & 38 \\
\hline \multirow[t]{2}{*}{ Crop system } & Monocrop & 1 & 40 & 26 & 14 \\
\hline & Intercrop & 1 & 118 & 58 & 62 \\
\hline \multirow[t]{2}{*}{ Weeds density } & $<70$ weeds $/ \mathrm{m}^{2}$ & 1 & 46 & 26 & 23 \\
\hline & $>70$ weeds $/ \mathrm{m}^{2}$ & 1 & 112 & 60 & 53 \\
\hline \multirow[t]{2}{*}{ Plant type } & Climber & 2 & 69 & 38 & 35 \\
\hline & Bush & 0 & 89 & 48 & 41 \\
\hline \multirow[t]{3}{*}{ Growth stage } & Flowering & 0 & 7 & 2 & 5 \\
\hline & Pre-podding & 1 & 57 & 36 & 22 \\
\hline & Pod filling & 1 & 94 & 36 & 21 \\
\hline \multirow[t]{2}{*}{ Year/season } & July 2011 & 2 & 84 & 51 & 33 \\
\hline & November 2012 & 0 & 76 & 33 & 43 \\
\hline
\end{tabular}

*Total number of fields $=160$

TABLE 4. Regression coefficients, standard error and P value effects of different independent variables on PSI of 160 fields in eastern Democratic Republic of Congo

\begin{tabular}{llcccc}
\hline No. & Variables & Coefficients & Standard Error & TStat & P-value \\
\hline 1 & Growth stage & 4.94 & 1.35 & 3.66 & $0.00^{* * *}$ \\
2 & Altitude & 9.84 & 3.29 & 2.98 & $0.00^{* * *}$ \\
3 & Districts & 2.74 & 1.05 & 2.62 & $0.00^{* *}$ \\
4 & Crop system & 4.54 & 1.79 & 2.52 & $0.01^{*}$ \\
5 & Season & 3.51 & 1.69 & 2.08 & $0.04^{*}$ \\
& & & & \\
& \multicolumn{2}{c}{ R-Square $=96.2 \%$} & & \\
\hline
\end{tabular}

*significantly different at $\mathrm{P}=0.05$ 
TABLE 5. Analysis of variance of severity (mode) values of Democratic Republic of Congo bean germplasm to isolate SK 146 in eastern Democratic Republic of Congo

\begin{tabular}{lrrrrl}
\hline Source of variation & \multicolumn{1}{c}{ DF } & \multicolumn{1}{c}{ SS } & MS & Fcal & F pr \\
\hline Replication & 2 & 0.15 & 0.07 & 0.27 & \\
Varieties & 40 & 697.17 & 17.43 & 61.15 & $<.001$ \\
Residual & 79 & 22.51 & 0.28 & & \\
Total & 121 & 709.38 & & & \\
\hline
\end{tabular}

TABLE 6. Analysis of variance of severity (mode values) bean germplasm to isolate SK 126 in eastern Democratic Republic of Congo

\begin{tabular}{lrrrr}
\hline Source of variation & DF & \multicolumn{1}{c}{ SS } & \multicolumn{1}{c}{ MS } & F pr \\
\hline Replication & 2 & 0.04878 & 0.02439 & \\
Varieties & 40 & 788.29268 & $19.70732^{* *}$ & $<.001$ \\
Residual & 80 & 5.95122 & 0.07439 & \\
Total & 122 & 794.29268 & & \\
\hline
\end{tabular}

TABLE 7. Mean score of resistant bean germplasm to ALS when challenged by isolate SK 126 in eastern Democratic Republic of Congo

\begin{tabular}{lcclcc}
\hline Varieties & $\begin{array}{c}\text { Mean of the } \\
\text { modal scores } \\
\text { per plot }\end{array}$ & Reaction & Grain colour & 100 seedweight & Size \\
\hline MEXICO 54 & 1.3 & $\mathrm{R}^{1}$ & Pink & - & - \\
ARA 4 & 2.0 & $\mathrm{R}$ & Red mottled & 42 & Large \\
CODMLV 059 & 2.0 & $\mathrm{R}$ & Red mottled & 45 & Large \\
LSA 144 & 2.0 & $\mathrm{R}$ & Red & 19 & Small \\
MLV 224/94B & 2.0 & $\mathrm{R}$ & Red & 33 & Medium \\
CAL 96 (Susceptible check) & 9 & $\mathrm{~S}$ & Red mottled & 44 & Large \\
\hline
\end{tabular}

$\mathrm{R}=$ Resistant 
TABLE 8. Mean score of resistant bean germplasm to ALS when challenged by isolate SK 146 in eastern Democratic Republic of Congo

\begin{tabular}{|c|c|c|c|c|c|}
\hline Varieties & $\begin{array}{c}\text { Mean disease } \\
\text { score }(1-9)\end{array}$ & Variety rank & Seed colour & 100 seed weight & Size \\
\hline CODMLV 059 & 1.9 & $\mathrm{R}$ & Red mottled & 45 & Large \\
\hline LSA 144 & 2.0 & $\mathrm{R}$ & Red & 19 & Small \\
\hline MEXICO 54 & 2.0 & $\mathrm{R}$ & Pink & - & Medium \\
\hline MLV 224/94B & 2.0 & $\mathrm{R}$ & Red & 33 & Medium \\
\hline RWR 362 & 2.0 & $\mathrm{R}$ & Red & 21 & Small \\
\hline ZKA 98-6M/95 & 2.0 & $\mathrm{R}$ & Purple & 15 & Small \\
\hline ARA 4 & 3.3 & $\mathrm{R}$ & Red mottled & 42 & Large \\
\hline RWR 2245 & 3.3 & $\mathrm{R}$ & Red mottled & 36 & Large \\
\hline CAL 96 (Susceptible check) & 9 & $\mathrm{~S}$ & Red mottled & 44 & Large \\
\hline
\end{tabular}

$\mathrm{R}=$ Resistant, $\mathrm{S}=$ Susceptible

\section{DISCUSSION}

Angular leaf spot evidently exists in the eastern Democratic Republic of Congo region. The study revealed that the disease is widespread across the different agro-ecological study zones. The high ALS prevalence, incidence (mean $=99.6 \%$ ) and severity (mean PSI=49.6), may be due to the farming practices adopted by smallholder farmers in the area; for instance use of poor quality farmer-saved seed (Njingulula, 2014), lack of crop rotation due to land scarcity, and poor management practices exacerbated by conducive environment conditions for disease development.

Cropping system. Regarding the influence of cropping systems on the prevalence of angular leaf spot, it is clear that the disease was slightly more severe under intercropping systems than the mono-cropping system. Crops such as maize (Zea mays L.), cassava (Manihot esculenta Crantz) and banana (Musa spp.) which were grown in association with common beans, may have created conducive microclimates, namely intermittent cool and warm, wet and dry conditions, respectively (Inglis and Hegedom, 1986; Saettler, 1991; Celetti et al., 2006) under their canopies for ALS infection and disease development (Potts,
1990). Contradictory results were reported by Boudreau (1993), who found significant reduction of ALS in a bean-maize intercrop in Kenya during the short rainy season, and no significant difference in the long rainy season. Similarly, Schoeny et al. (2010) reported reduced severity aschochyta blight on pods and stems in a pea-cereal intercropping system compared to mono-cropping in western France.

The study showed that ALS severity was highest in the higher altitudes compared to the lower altitude areas (Table 2). In a similar study done in Kenya, it was observed that ALS disease severity was high at altitudes ranging between 1601 and 2000 m.a.s.l. (Mwangombe et al., 2007). This finding may be attributed to the high rainfall and relative humidity common in the high altitudes that are more favourable to ALS infection and disease development. It has been reported that altitude affects temperature and rate of evaporation, and in so doing also influences the incidence and severity of certain diseases (Wortmann et al.,1998). Steinglein et al. (2003) reported that moderate temperatures and high relative humidity were the most favourable conditions for the fungal disease epidemic development. Whereas, Sahile et al. (2008) observed that altitude alone had no effect on the development of chocolate spot, the interaction of altitude 
and season had an effect on the diseases development.

This points to the need to undertake multiyear/multi-season studies of ALS across different altitudinal ranges in eastern DRC. This study showed that ALS severity varies between locations and seasons. Fluctuating weather conditions, especially relative humidity, temperature, and rainfall) have been reported to favour diseases development under fields conditions (Correa-Victoria et al.,1989; Anderson et al., 2004). Scheuemann et al. (2012) suggested that disease occurrence and severity may vary by year, location and even within field depending on environmental conditions and crop management practices. In contrast, Belete et al. (2013) did not find any association between elevation and Fusarium root rot disease of Fabae beans in Northern Ethiopia.

Angular leaf spot resistance. Four common bean varieties from INERA, Mulungu showed resistance to virulent ALS isolates from eastern DRC (Table 7). Varieties: LSA 144, a red small seeded, ARA 4 a red mottled large seeded, COD MLV 059, a red mottled large seeded and MLV 224/94B, a red medium, were resistant to ALS disease when inoculated with two virulent $P$. griseola isolates (Tables 7 and 8 ). The same trend was true for variety Mexico 54, a known source of ALS resistance (Sartotato et al., 2000). This shows that varieties from DRC may also carry useful ALS resistance genes and could be important sources for ALS resistance. Similarly, variety Mexico 54 is a potential source of resistance to manage ALS disease in DRC.

A single dominant resistance gene, " $P h-2$ " that governs resistance in Mexico 54 was reported by Sartorato et al.(2000). Later, it was suggested that ALS resistance in Mexico 54 is governed by two genes, " $P h-2$ " and " $P h$ 5" (Caxieta et al., 2005). However, physical linkage information was not provided and this genetic hypotheses still needs to be validated (Souza et al., 2015).
Variety G5686, also a documented source of resistance (Mahuku et al., 2009) showed intermediate reaction to the two isolates, representing Andean and Mesoamerican group, SK 126:pathotype 61-39 and SK 146:pathotype 57-39. G5686 has been reported to possess three dominant and complementary genes conditioning resistance to pathotype 31-0 (Mahuku et al., 2009).

Another documented source of resistance that exhibits high to intermediate levels of resistance to ALS in several countries of eastern and southern Africa, CAL 143 (Aggrawal et al., 2004), exhibited intermediate disease reaction to the two $P$. griseola isolates. However, in previous studies, CAL 143 showed intermediate reaction to pathotype 7-55 in DRC, and was found to be susceptible in Uganda (Aggrawal et al., 2004). Most recently the major QTL ALS4.1 ${ }^{\mathrm{GS}, \mathrm{UD}}$ on Pv04, present in G5686, and the ALS10.1 ${ }^{\mathrm{DG}, \mathrm{UC}}$ on Pv10, identified in both G5686 (Keller et al., 2015) and CAL143 (Oblessuc et al. (2012, 2013) were officially named as Phg-4 and Phg-5 (Souza et al., 2015;).

Although small seeded common bean genotypes have been previously reported to be more resistant to ALS compared to the large seeded ones (Pyndji and Trutmann, 1992), this study identified two large seeded bean varieties (ARA 4 and MLV 059) with good levels of resistance to ALS (Tables 7 and 8). These varieties are potential sources of resistance to ALS in eastern DRC in the Andean background. Besides, being a potential source of resistance to angular leaf spot, ARA 4 has market-desired characters and is tolerant to multiple stresses, specifically poor soil fertility (Lunze et al., 2002). Varieties MLV059 and COD MLV224/ 94B are breeding lines developed at INERA Mulungu; while varieties LSA 144 and ARA 4 were derived from the CIAT nursery, BILFA (Beans for low soil Fertility in Africa) selected for tolerance to acidic soils (Lunze et al., 2012). These varieties could be promoted in areas where ALS is a constraint. Similarly, the identified ALS resistant varieties may be used 
as parents in breeding programmes for ALS resistance; host resistance being one of the most effective, economically and friendly strategies for managing ALS disease (Pastor Corrales and Singh, 1999) and also promoted in ALS prone areas for food production. However, the nature of the resistance needs to be explored so as to be appropriately exploited.

\section{CONCLUSION}

ALS is a major bean disease in the two main bean agro-ecological zones of eastern Democratic Republic of Congo (DRC) in Kivu Province. Poor farming practices such as the use of poor quality farmer-saved seed, lack of crop rotation due to land scarcity, and poor management practices that are common among the smallholder bean farmers, may have contributed to the high ALS prevalence. ALS severity is influenced by locations and varied from one season/year to another, with the highest severity being observed in Kabareat moderately high altitude, and the lowest in Uvira, located in low altitude in both long and short rainy season. The need to undertake multi-year studies of ALS across different altitudinal ranges in eastern DRC is highlighted.These locations with high ALS severity are suitable as high disease spot areas for ALS screening, while the ones with lowest score are appropriate for seed multiplication. Using representative virulent isolates from DRC, to screen for ALS resistance, allowed us to identify four resistant varieties among DRC bean germplasm. Host resistance is recognised as an effective strategy to manage ALS disease, and as such, these varieties may be used as parents in the breeding programme for ALS resistance or promoted as varieties in ALS infected areas in Eastern DRC. However, their utility to benefit other bean growing regions requires further testing in more sites. In addition, the nature of the resistance in these lines needs to be explored so as to be appropriately exploited.

\section{ACKNOWLEDGMENT}

The study was funded by the Pan African Bean Research Alliance (PABRA) Programme of the International Centre for Tropical Agriculture (CIAT).

\section{REFERENCES}

Aggarwal, V.D., Pastor-Corrales, M.A., Chirwa, R.M. and Buruchara, R.A. 2004. Andean beans (Phaseolus vulgaris L.) with resistance to the angular leaf spot pathogen (Phaeoisariopsis griseola) in southern and eastern Africa. Euphytica 136(2):201-210.

Allorent, D. and Savary, S. 2005. Epidemiological characteristics of angular leaf spot of bean: A systems analysis. European Journal of Plant Pathology 113(4):329-341.

Belete, E., Ayelew, A. and Ahmed, S. 2013. Association of biophysical factors with fabae bean root rot (Fusarium solani) epidemics in northestern highilands of Ethiopia. Crop Protection 52:39-46.

Boudreau, M. 1993. Effect of intercropping beans with maize on the severity of angular leaf spot of beans in Kenya. Plant Pathology 42(1):16-25.

Busogoro, J., Jijakli, M. and Lepoivre, P. 1999. Virulence variation and RAPD polymorphism in African isolates of Phaeoisariospis griseola (Sacc.) Ferr., the causal agent of angular leaf spot of common bean. European Journal of Plant Pathology 105(6):559-569.

Celetti, M.J., Melzer, M.S. and Boland, G.J. 2006. Fact sheet for angular leaf spot of snap beans, Ministry of Agriculture Food and Rural Affairs Ontario, Canada.

Correa-Victoria, F.J., Pastor-Corrales, M.A. and Saettler, A.W. 1989. Angular leaf spot. In: Schwartz, H.F. and Pastor-Corrales, M.A. (Ed.), Bean production problems in the tropics (second ed.), pp. 726).CIAT Cali Colombia. 
Crabb, A.C., Marois, J.J. and Salmon, T.P. 1994. Evaluation of field sampling techniques for estimation of bird damage in pistachio orchards. Paper presented at the Proceedings of the Sixteenth Vertebrate Pest Conference (1994).

Crous, P.W., Liebenberg, M.M., Braun, U. and Groenewald, J.Z. 2006. Re-evaluating the taxonomic status of Phaeoisariopsis griseola, the causal agent of angular leaf spot of bean. Studies in Mycology 55(1):163-173.

Delp, B., Stowell, L. and Marois, J. 1986. Evaluation of field sampling techniques for estimation of disease incidence. Phytopathology 76(12):1299-1305.

FAO. 2010. Agricultural production.www. faostat.fao.org/site/567/default.aspx Retrieved 09/11/2012, 2012.

Fernández-Aparicio, M., Shtaya, M., Emeran, A., Allagui, M., Kharrat, M. and Rubiales, D. 2011. Effects of crop mixtures on chocolate spot development on faba bean grown in mediterranean climates. Crop Protection 30(8):1015-1023.

Fininsa, C. and Yuen, J. 2002. Temporal progression of common bacterial blight (Xanthomonas compestris pv phaseoli) in sole and intercropping systems. European Journal of Plant Patiopathology 108:185185

Inglis, D.A. and Hagedom, D.J. 1986. Temperature requirements by Isariopsis griseola for infection and disease development on red kidney beans. Annual Report of the Bean Improvement Cooperative. pp. 29-35.

Katungi, E., Farrow, A., Chianu, J., Sperling, L. and Beebe, S. 2009. Common bean in Eastern and Southern Africa: A situation and outlook analysis. International Centre for Tropical Agriculture, 61.

Keller, B., Manzanares, C., Jara, C., Lobaton J.D., Studer, B. and Raatz, B. 2015. Finemapping of a major QTL controlling angular leaf spot resistance in common bean (Phaseolus vulgaris L.). Theoretical Applied Genetics 128:813-826.

Lunze, L.,Kimani, P.M., Ndakidemi, P., Rabary, B., Rachier, G.O., Ugen, M. and Nabahungu, L. 2002. Selection of bean lines tolerant to low soil fertility conditions in Africa. Bean Improvement Cooperative 45: 182-183.

Lunze, L., Abang, M., Buruchara, R., Ugen, M., Nabahungu, L. and Rachier, G. 2012. Integreted soil fertility mangement in beanbased cropping systems of Eastern Central and Southern Africa. In: Whalen (Ed.). Soil fertility improvement and integrated nutrient management - A Global Perspective. ISBN: 978-307-945-5, Intech, DOI:10.55772/ 29151.P 240-272.

Mahuku, G.S., Henríquez, M.A., Munõz, J. and Buruchara, R.A. 2002. Molecular markers dispute the existence of the AfroAndean group of the bean angular leaf spot pathogen, Phaeoisariopsis griseola. Phytopathology 92(6):580-589.

Mahuku, G.S., Iglesias, Á.M. and Jara, C. 2009. Genetics of angular leaf spot resistance in the Andean common bean accession G5686 and identification of markers linked to the resistance genes. Euphytica 167(3):381-396.

Musila, C. 2009. Le Kivu charniere entre l'Atlantique et l'Ocean Indien.

Mwangombe, A., Wagara, I., Kimenju, J. and Buruchara, R. 2007. Occurrence and severity of angular leaf spot of common bean in Kenya as influenced by geographical location, altitude and agroecological zones. Plant Pathology Journal 6.

Njingulula, P., Wimba, M., Musakamba, M., Masukim, K.F., Katafire, M. and Ugen, M. 2014. Strengthening local seed systems within the bean value chain experience of agricultural innovation platforms in the democratic republic of Congo. African Crop Science Journal 22 (Issue Supplement):1003-1012. 
Oblessuc, P.R., Baroni, R.M., Garcia, A.A.F., Chioratto, A.F., Carbonell, S.A.M., Camargo, L.E.A. and Benchimol, L.L. 2012. Mapping of angular leaf spot resistance QTL in common bean (Phaseolus vulgaris L.) under different environments. BMC Genet 13(50):9. doi:10.1186/1471-2156-13-50Google Scholar.

Oblessuc, P.R., Perseguini, J., Baroni, R.M,. Chiorato, A.F., Carbonell, S.A.M., Mondego, J.M.C., Vidal, R.O., Camargo L.E.A. and Benchimol-Reis, L.L. 2013. Increasing the density of markers around a major QTL controlling resistance to angular leaf spot in common bean. Theoretical Applied Genetics 126(10): 2451-2465. doi:10.1007/s00122-013-21461

Pastor-Corrales, M., Jara, C. and Singh, S. P. 1998. Pathogenic variation in, sources of, and breeding for resistance to Phaeoisariopsis griseola causing angular leaf spot in common bean. Euphytica 103(2):161-171.

Potts, M.J. 1990. Influence of intercropping in warm climates on pests and diseases of potato, with special reference to their control. Field Crops Research 25(1):133144.

Pyndji and Trutmann, P. 1992. Managing angular leaf spot on common beans in Africa by supplementing farmer mixtures with resistent varieties. Plant Disease 76:1144-1147.

Pyndji, M. 1992. Pathogenic variability of Phaseoisariopsis griseola in the Great Lakes region. Paper presented at the Pan African Bean pathology workshop group meeting, Thika Kenya.

Saettler, A.W. 1991. Angular leaf spot. In: Compendium of bean diseases, 15-16. Hall, R. (Ed.). APS Press.St Paul, USA.

Sahile, S., Ahmed, S., Fininsa, C., Abang, M. M. and Sakhuja, P.K. 2008. Survey of chocolate spot Botrytis fabae disease of faba bean (Vicia faba L.) and assessment of factors influencing disease epidemics in northern Ethiopia. Crop Protection 27(11):1457-1463.

Scheuermann, K.K., Raimondi, J.V., Marschalek, R., de Andrade, A. and Wickert, E. 2012. Magnaporthe oryzae genetic diversity and its outcomes on the search for durable resistance. Mahmut Caliskan (Ed.). ISBN 978-953-51-01574. The Molecular Basis of Plant Genetic Diversity, Chapter 15: 331-356.

Schoeny, A., Jumel, S., Rouault, F., Lemarchand, E. and Tivoli, B. 2010. Effect and underlying mechanisms of pea-cereal intercropping on the epidemic development of ascochyta blight. European Journal of Plant Pathology 126(3): 317-331.

Schoonhoven, A.V. and Pastor-Corrales, M. (Eds.). 1987. Standard system for the evaluation of bean germplasm: CIAT. Cali Colombia.

Singh. 2007. Revised Introductory Plant Pathology.

Souza, T.P.O., Gonçalves-Vidigal, M.C., Bodo, R. Mukankusi, C.M., Abreu, A.F.B., Melo, L.C. and Pastor-Corrales, M.A. 2015. Major loci controlling resistance to the angular leaf spot of common bean. https:/ /www.alice.cnptia.embrapa.br/alice/ bitstream/doc/1047558/.../CNPAF 2016xv.p...

Stenglein, S., Ploper, L.D., Vizgarra, O. and Balatti, P. 2003. Angular Leaf Spot: A disease caused by the fungus Phaeoisariopsis griseola (Sacc.) Ferraris on Phaseolus vulgaris L. Advances in Applied Microbiology 52:209-243.

USAID. 2010. USAID office food for peace Republique Democratique of Congo Belmon Estimation USAID.

Wortmann, C., Kirkby, R., Eledu, C. and Allen, D. 1998. Atlas of common bean (Phaseolus vulgaris L.) Production in Africa. Cali. Colombia CIAT pulbication No. 297. ISBN 958-9439-94-2. 